\title{
Antiangiogenic Therapy for Ischemic Retinopathies
}

\author{
Motasem Al-Latayfeh, Paolo S. Silva, Jennifer K. Sun, and Lloyd Paul Aiello \\ Beetham Eye Institute, Joslin Diabetes Center, Boston, Massachusetts 02215; and Department \\ of Ophthalmology, Harvard Medical School, Boston, Massachusetts 02215 \\ Correspondence: Ipaiello@joslin.harvard.edu
}

\begin{abstract}
Neovascularization is a common pathological process in various retinal vascular disorders including diabetic retinopathy (DR), age-related macular degeneration (AMD) and retinal vein occlusion (RVO). The development of neovascular vessels may lead to complications such as vitreous hemorrhage, fibrovascular tissue formation, and traction retinal detachments. Ultimately, irreversible vision loss may result. Various proangiogenic factors are involved in these complex processes. Different antiangiogenic drugs have been formulated in an attempt treat these vascular disorders. One factor that plays a major role in the development of retinal neovascularization is vascular endothelial growth factor (VEGF). Anti-VEGF agents are currently FDA approved for the treatment of AMD and RVO. They are also extensively used as an off-label treatment for diabetic macular edema (DME), proliferative DR, and neovascular glaucoma. However, at this time, the long-term safety of chronic VEGF inhibition has not been extensively evaluated. A large and rapidly expanding body of research on angiogenesis is being conducted at multiple centers across the globe to determine the exact contributions and interactions among a variety of angiogenic factors in an effort to determine the therapeutic potential of antiangiogenic agent in the treatment of a variety of retinal diseases.
\end{abstract}

T he development of neovascularization and vascular leakage is one of the key pathological processes that leads to sight threatening complications in nearly all retinal vascular diseases including diabetic retinopathy (DR) (Sun et al. 2008), age-related macular degeneration (AMD) (Jager et al. 2008), and retinal vein occlusion (RVO) (McIntosh et al. 2010; Rogers et al. 2010). Neovascularization is characterized by the growth of blood vessels that are morphologically and functionally abnormal. Neovascular blood vessels can be highly proliferative but are often structurally deficient and poorly organized as compared with normal, mature vessels. This may result in fragile neovascular fronds that tend to grow on the surface of the retina without the branching pattern characteristic of normal retinal vessels (Henkind and Wise 1974). The development of these neovascular vessels may lead to retinal complications such as vitreous hemorrhage, fibrovascular tissue formation, and traction retinal detachments, often ultimately leading to vision loss (Adamis et al. 1999). The specific structural and functional abnormalities present in neovascular vessels provide targets for the design of novel therapeutic and treatment strategies.

Editors: Michael Klagsbrun and Patricia D'Amore

Additional Perspectives on Angiogenesis available at www.perspectivesinmedicine.org

Copyright (C) 2012 Cold Spring Harbor Laboratory Press; all rights reserved; doi: 10.1101/cshperspect.a006411

Cite this article as Cold Spring Harb Perspect Med 2012;2:a006411 
M. Al-Latayfeh et al.

The current standard of care for the majority of ischemic retinal diseases is laser photocoagulation. This treatment approach has been proven effective in large randomized clinical trials at inducing long-term regression of neovascularization; however, such treatment can be associated with potentially vision threatening side-effects and a proportion of patients still continue to develop active neovascularization and consequent visual loss (Chew et al. 2003).

The use of antiangiogenic agents for the treatment of various retinal diseases has recently emerged as a potential adjunct to standard ophthalmic care for ocular neovascularization (Gragoudas et al. 2004; Rosenfeld et al. 2006; Brown et al. 2009; Elman et al. 2010). The majority of antiangiogenic agents with evidence of clinical efficacy at this time generally act by inhibiting vascular endothelial growth factors (VEGF). Anti-VEGF therapies have been shown to be remarkably effective in preventing vision loss from the neovascular and exudative complications of retinal diseases particularly in AMD (Gragoudas et al. 2004; Rosenfeld et al. 2006; Andreoli and Miller 2007; Bashshur et al. 2009) and DR (Elman et al. 2010). They also have the benefit, unlike laser photocoagulation, of not being inherently destructive to the retina and benefits compared with steroids in not causing cataract or elevations in intraocular pressure. Although VEGF plays a major role in these diseases and appears to be an excellent therapeutic target, whether VEGF, another factor, or a combination of factors is the optimal target for antiangiogenic therapy of proliferative retinopathies still remains unanswered. Here, we will discuss the various antiangiogenic therapeutic approaches applicable to the treatment of neovascular retinal disease.

\section{KEY ANGIOGENIC GROWTH FACTORS INVOLVED IN PROLIFERATIVE RETINOPATHIES}

Angiogenic factors have been shown to be central in the pathogenesis of proliferative retinopathies. Of these factors, VEGF has received the most attention in recent years and appears to be responsible for the majority of intraocular angiogenesis of ischemic origin (Aiello et al. 1994; Miller et al. 1994; Pierce et al. 1995). This is especially evident in ischemic retinal diseases such as proliferative diabetic retinopathy, rubeosis iridis, and central retinal vein occlusion (Aiello et al. 1994). Other factors such as angiopoietin, erythropoietin, basic fibroblast growth factor (bFGF), insulin like growth factor (IGF), protein kinase C (PKC) enzymes, TGF, PDGF, and others may have moderating roles. VEGF-A is a heparin-binding homodimeric glycoprotein of $45 \mathrm{kDA}$ (Ferrara and Henzel 1989). The human VEGF-A gene is organized in eight exons, separated by seven introns (Tischer et al. 1991). Alternative exon splicing results in the generation of four different isoforms: $\mathrm{VEGF}_{121}, \mathrm{VEGF}_{165}$, which is the most prevalent human form, $\mathrm{VEGF}_{189}$ and $\mathrm{VEGF}_{206}$ (Houck et al. 1991; Tischer et al. 1991). VEGF secretion is dramatically induced by hypoxia (Dor et al. 2001; Semenza 2003) as are other growth factors (epidermal growth factors, TGF, IGF, and PDGF) and some hormones (TSH, ACTH, hCG, and sex hormones) (Ferrara 2004). VEGF is associated with breakdown of blood-retina barrier and increased vascular permeability of the retinal blood vessels $(\mathrm{Mu}-$ rata et al. 1995; Mathews et al. 1997).

Angiopoietins are a group of proteins that potentiate the angiogenic effect of other angiogenic cytokines, in particular VEGF. Angiopoietin-1 (Ang-1) promotes vascular network maturation, whereas angiopoietin-2 (Ang-2) initiates neovascularization (Asahara et al. 1998). Both angiopoietins interact with a tyrosine kinase receptor called Tie-2 receptor (Suri et al. 1996; Maisonpierre et al. 1997). The angiopoietin/Tie-2 system has an important role in the pathogenesis of proliferative diabetic retinopathy (Takagi et al. 2003; Cai et al. 2008).

The PKC family is a group of isoenzymes that are involved in intracellular signaling. PKC is involved in some aspects of VEGF expression in diabetic retinopathy although oral therapy does not seem to significantly prevent progression to PDR (Aiello 2002; PKC-DRS Study Group 2005; PKC DRS et al. 2006; PKC-DMES Study Group 2007; Girach et al. 2009). 
Erythropoietin stimulates red blood cell formation in response to low-oxygen tension (Jelkmann 1992). It also promotes angiogenic activity in vascular endothelial cells (Carlini et al. 1995; Ribatti et al. 1999). In the eye, erythropoietin is a potent retinal angiogenic factor independent of VEGF and is capable of stimulating ischemia-induced retinal angiogenesis in proliferative diabetic retinopathy (Watanabe et al. 2005). In addition, the plasma kallikreinbradykinin system has been implicated in the increased retinal vascular permeability mediated by angiotensin and carbonic anhydrase enzymes, also through a VEGF independent mechanism (Gao et al. 2007; Phipps et al. 2009).

\section{ANTIANGIOGENIC DRUGS USED FOR THE TREATMENT OF EYE DISEASES}

There are three main mechanisms by which antiangiogenesis agents are used for the treatment of proliferative retinopathies. These mechanisms include: (1) Inhibition of VEGF through direct binding; (2) Inhibition of VEGF synthesis; and (3) Inhibition of VEGF signaling.

Currently there are four agents that inhibit of VEGF through direct binding that are being evaluated or used for the treatment of proliferative retinal diseases: Pegaptanib, Bevacizumab, Ranibizumab, and VEGF Trap. Pegaptanib is a pegylated ribonucleic acid aptamer that specifically binds human $\mathrm{VEGF}_{165}$ with high affinity (Ruckman et al. 1998). Bevacizumab is a humanized form of the murine anti-VEGF-A antibody. It can block all forms of VEGF-A. It was originally FDA approved for treatment of metastatic colon cancer, and has since been approved for chemotherapeutic use in multiple other cancers (Ferrara et al. 2005). It is not FDA approved for any ocular indication. Ranibizumab is an optimized Fab fragment of the anti-VEGF-A antibody bevacizumab. It binds and inhibits all isoforms of VEGF-A (Rosenfeld et al. 2005). It has FDA approval for intraocular use for treatment of neovascular AMD and macular edema secondary to retinal vein occlusion. VEGF trap is a novel fusion decoy protein that is specifically designed to bind all forms VEGF and PDGF with a very high affinity. It is constructed by fusing specific domains from VEGF Receptors 1 and 2 with Fab fragment of IgG resulting in an extremely high affinity for $\operatorname{VEGF}\left(\mathrm{kD}\right.$ of $\approx 1-10 \mathrm{pM}$ for $\mathrm{VEGF}_{121}$ ) (Holash et al. 2002).

An approach to inhibition of VEGF synthesis has involved the use of small-interfering RNA (siRNA) sequences that silence specific genes that have homology with the injected siRNA sequences. The delivery of siRNA sequences directed against the VEGF gene can potentially inhibit both synthesis and secretion of intracellular VEGF by blocking VEGF gene expression (Kaiser 2006).

Certain tyrosine kinase receptor inhibitors and peroxisome proliferators-activated receptor- $\gamma$ (PPAR- $\gamma$ ) agonists can inhibit VEGF signaling. VEGF exerts its action by stimulating high-affinity receptors on endothelial cells. The signaling mechanism involves tyrosine residue phosphorylation of the receptors (Aiello et al. 1995). Inhibiting tyrosine kinase activity can result in significant suppression of the neovascular activity of VEGF (Aiello et al. 1997). PPAR $\gamma$ agonists angiogenesis in animal models by indirectly affecting the function of VEGF (Panigrahy et al. 2002). PPAR- $\gamma$ agonists such as rosiglitazone and pioglitazone have been used clinically to decrease insulin resistance and improve glycemic control (Aljada et al. 2008). Interestingly, use of Rosiglitazone may delay the onset of proliferative retinopathy in type 2 diabetes because of its antiangiogenic properties (Fig. 1) (Shen et al. 2008).

\section{THE USE OF ANTIANGIOGENIC DRUGS BY DISEASE}

\section{Age-Related Macular Degeneration}

AMD is the leading cause of blindness in the population over 65 years of age in USA, Europe, and Australia (Congdon et al. 2004). There are two main types of AMD: nonneovascular and neovascular. Nonneovascular AMD is characterized by the presence of hard or soft drusen and retinal pigment epithelial (RPE) changes. Geographic atrophy of the RPE is present in advanced nonneovascular AMD (Bressler et al. 
M. Al-Latayfeh et al.

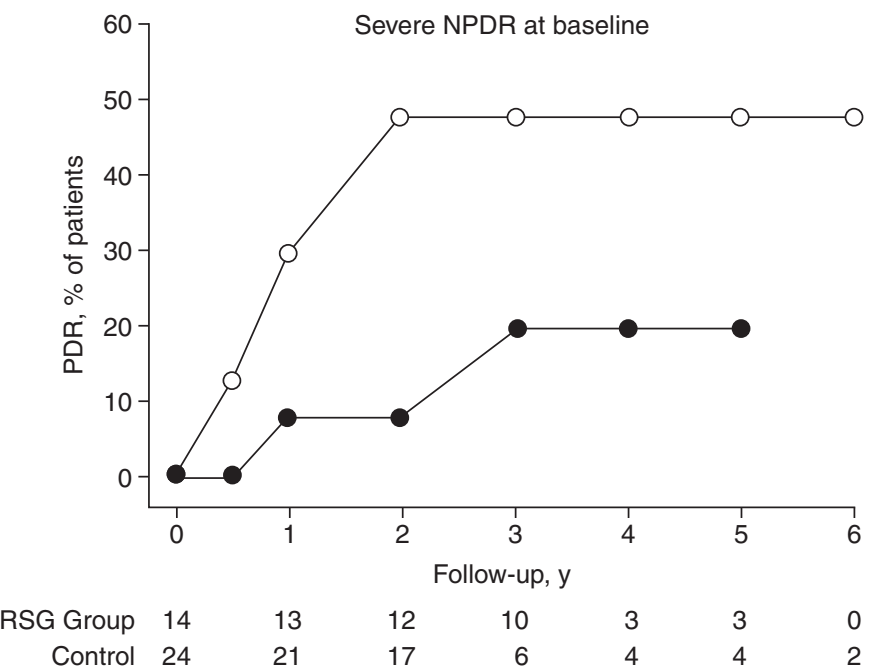

Figure 1. Effect of rosiglitazone on the onset of proliferative diabetic retinopathy patients with severe nonproliferative diabetic retinopathy (NPDR) at baseline. Kaplan-Meier survival curve showing cumulative percentage progression to proliferative diabetic retinopathy (PDR) for patients treated with rosiglitazone (RSG) and control patients. (50) The number of eyes in each group with more than one follow-up visit and at the beginning of each follow-up interval is indicated below the $\mathrm{x}$-axis. $P=.045$ by Wilcoxon method. (Figure derived from Shen et al. 2008; reprinted, with permission, from the author.)

1988). In contrast, neovascular AMD is characterized by the presence of choroidal neovascular membranes (CNVM) that are often associated with subretinal fluid, hemorrhage, and eventually subretinal fibrosis and loss of vision (Votruba and Gregor 2001). Key risk factors for AMD include advanced age and positive family history of $\mathrm{AMD}$, race, smoking, and hypertension (Age-Related Eye Disease Study Research Group 2000; Klein et al. 2004; Clemons et al. 2005).

\section{Angiogenesis in AMD}

The pathology in AMD is a result of a combination of multiple mechanisms, some of which are not as yet completely understood. Oxidative stress is believed to be an important contributing factor to the development of AMD (Beatty et al. 2000; Age-Related Eye Disease Study Research Group 2001). Age-related inflammatory processes have also been implicated. Genetic variations in the factor $\mathrm{H}$ gene are highly associated with an increased risk of AMD (Edwards et al. 2005). Factor $\mathrm{H}$ is a major inhibitory factor for the complement system and gene mutations may led to sustained activation of the complement system that resulting in photoreceptor and RPE atrophy, and Bruch's membrane disruption with resultant choroidal neovascularization (Donoso et al. 2006).

The development of CNVM presumably results from an increase in angiogenic stimuli that overcome compensatory antiangiogenic mechanisms in the eye. This imbalance may be the result of tissue hypoxia, inflammation or a combination of both. VEGF is found in high concentrations in the CNVM of patients with AMD, while in contrast, pigment-epithelium derived factor (PEDF), a photoreceptor neurotrophic factor with antiangiogenic properties, is found to have lower concentrations in the vitreous with advancing age (Nowak 2006).

\section{Therapies for AMD: Role of Antiangiogenic Drugs}

Identifying an effective treatment approach to limit visual complications and improve visual outcomes in neovascular AMD has been the 
subject of much research. Laser photocoagulation of CNVM was used initially in an attempt to preserve vision. Laser treatment reduced the rate of severe visual loss (loss of six lines or more), preserved patient reading speed and maintained stable contrast sensitivity (Macular Photocoagulation Study Group 1993). However, this treatment modality is not appropriate for patients with subfoveal lesions, and is associated with a high recurrence rate of up to $51 \%$ (Macular Photocoagulation Study Group 1991).

Photodynamic therapy (PDT), which uses the combination of photosensitizing agents and low energy laser to achieve selective destruction of CNVM (Miller et al. 1999), is another treatment option. PDT was the first treatment approach found to be effective by large randomized clinical trials for subfoveal lesions. Two major clinical trials, Treatment of Age-related Macular Degeneration With Photodynamic Therapy (TAP) and Verteporfin In Photodynamic therapy (VIP), showed that fewer patients in the PDT group lost 15 letters of vision as compared with the placebo group $(37 \%-54 \%$ vs. $62 \%-67 \%$, duration of follow-up $=24$ months) (Bressler 2001; Verteporfin in Photodynamic Therapy Study Group 2001). However, patients with good initial visual acuity or larger subfoveal lesions had a less favorable outcome (Bressler 2001; Verteporfin in Photodynamic Therapy Study Group 2001). Despite the initial success in preventing immediate blindness, the rate of vision improvement remained low, with only $13 \%-$ $16 \%$ of patients gaining one line or more of vision (Bressler 2001; Verteporfin in Photodynamic Therapy Study Group 2001).

A dramatic advancement in the treatment of neovascular AMD was attained with the introduction of antiangiogenic drugs. Multiple large randomized trials established the efficacy of treatment with anti-VEGF agents not only to reduce the incidence of vision loss, but also improve vision in more than $30 \%$ of patients (Gragoudas et al. 2004; Rosenfeld et al. 2006; Brown et al. 2009).

Gragoudas et al. showed that pegaptanib reduced the incidence of moderate and severe visual loss in the treatment groups. The percentage of patients who lost less than 15 letters increased from $55 \%$ in the control group to $70 \%$ in the treatment groups. In addition, the incidence of severe vision loss dropped from $22 \%$ in the control group to $10 \%$ in the treatment groups. Mean visual acuity was significantly better in the treatment groups as compared with the control group (Gragoudas et al. 2004).

Two of the largest trials in AMD, the MARINA (Minimally Classic/Occult Trial of the Anti-VEGF Antibody Ranibizumab in the Treatment of Neovascular Age-Related Macular Degeneration) and ANCHOR (Anti-VEGF Antibody for the Treatment of Predominantly Classic Choroidal Neovascularization in AgeRelated Macular Degeneration) trials, established the efficacy of ranibizumab compared to sham injection and PDT in preventing visual loss in patients with CNVM (Rosenfeld et al. 2006; Brown et al. 2009). The MARINA trial is a phase III trial that compared two doses of ranibizumab $(0.3 \mathrm{mg}$ or $0.5 \mathrm{mg})$ to sham injections in patients with occult or minimally classic CNVM. It showed that the percentage of patients that lost less than three lines of vision in both ranibizumab groups was $95 \%$ compared to $62 \%$ in the sham group after 1 year. Also, about one third of patients in the ranibizumab groups gained more than three lines of vision compared to $2 \%$ in the control group (Rosenfeld et al. 2006). The ANCHOR trial compared repeated intravitreal injections of two doses of ranibizumab $(0.3 \mathrm{mg}$ and $0.5 \mathrm{mg}$ ) to PDT in patients with predominantly classic CNVM. The results showed that the percentage of patients who lost fewer than 15 letters was $90 \%$ and $90 \%$ for the $0.3 \mathrm{mg}$ and $0.5 \mathrm{mg}$ ranibizumab groups, respectively, as compared with $66 \%$ of those in the verteporfin group. Visual acuity improved by 15 letters or more in 34\% of the $0.3-\mathrm{mg}$ group and $41 \%$ of the $0.5-\mathrm{mg}$ group, as compared with $6 \%$ of the verteporfin group (Brown et al. 2009). The PIER study is another phase III study that attempted to compare two doses of ranibizumab $(0.3 \mathrm{mg}$ and $0.5 \mathrm{mg}$ ) given monthly for the first three months then quarterly for 12 months, with sham injection. The 12-month results showed 
M. Al-Latayfeh et al.

that treatment with ranibizumab resulted in significantly less vision loss compared to sham group (mean letter change in both ranibizumab groups was -1.6 and -0.2 letters compared to -16.3 in the sham group, $p<0.0001)$. In addition, the percentage of patients who lost less than 15 letters was $83 \%$ and $90 \%$ for the $0.3 \mathrm{mg}$ and $0.5 \mathrm{mg}$ ranibizumab groups respectively, compared to $49 \%$ in the sham group (Regillo et al. 2008). The 24-month results showed that the visual benefits in the first 12 months of the study were maintained through the second year. However, both ranibizumab groups were switched to a monthly regimen after month 19. The PIER report concluded that the visual outcome of the quarterly regimen is not as robust as the monthly regimen followed in the MARINA and the ANCHOR studies (Abraham et al. 2010).

All the above mentioned studies, as well as others, have reported a good safety profile for intravitreal ranibizumab in AMD. The per-injection rate of endophthalmitis has been less than $0.1 \%$ in all studies. One phase IIIb study has found a nonstatistically significant difference toward a higher rate of cerebrovascular stroke in the $0.5 \mathrm{mg}$ ranibizumab group versus the control group, but no such trend was observed for myocardial infarction or arterial thrombotic events overall (Boyer et al. 2009).

Intravitreal bevacizumab was initially reported to be effective in AMD in several small clinical trials of relatively short duration (Bashshur et al. 2009; Rosenfeld et al. 2005a). More recent results from a large phase III, multicenter randomized controlled trial, the Comparison of Age-related Macular Degeneration Treatments Trials (CATT), have showed that bevacizumab, when used for treatment of neovascular AMD by the same protocol as ranibizumab (either dosed monthly or on a prn basis), is noninferior to the use of ranibizumab (CATT research Group et al. 2011). Rates of thromboembolic events, including death, myocardial infarction, and stroke, were also similar between patients who received bevacizumab as compared with ranibizumab. The proportion of patients with serious systemic adverse events was higher in the bevacizumab treated group, but these events were not related to complications that had previously been identified as relating to anti-VEGF therapy.

Other agents are also being investigated for treatment of AMD. Initial trials on VEGF trap showed that it appears effective and well tolerated in AMD patients (Nguyen et al. 2009). Phase II trials have also shown improvements in vision and reductions in retinal thickness with the use of VEGF trap as treatment for neovascular AMD over up to a 1-year period (Brown et al. 2011; Heier et al. 2011). Phase III trials (VIEW1 and VIEW2) are now underway to establish the clinical efficacy of VEGF trap compared to ranibizumab. Also, bevasiranib, which is a siRNA molecule known previously as Cand5, showed some efficacy in reducing the rate of vision loss in AMD when combined with ranibizumab (Singerman 2009). Another group of drugs that are currently being evaluated for AMD are tyrosine kinase receptor blocking agents for which animal studies have shown that some topical agents result in up to $58 \%$ reduction of the size of the CNVM in rats with no apparent ocular or systemic toxicity (Takahashi et al. 2009). Clinical trials are ongoing. Results are expected within the next few years and could potentially further improve the visual outcomes in patients with neovascular AMD.

\section{CHOROIDAL NEOVASCULARIZATION IN OTHER DISEASES}

CNVM is a pathologic feature in various diseases other than AMD such as pathologic myopia, angioid streaks, ocular histoplasmosis, and traumatic choroidal rupture. In a controlled clinical trial that compared bevacizumab with PDT in myopic CNV, $49 \%$ of the bevacizumab treatment group gained two lines or more of vision after single injection with a sustained effect over 1 year. The mean best-corrected visual acuity (BCVA) improved more in the bevacizumab group compared to the PDT or control groups. In addition, treatment with bevacizumab resulted in more regression of CNVM and less chorioretinal atrophic changes compared to the PDT group (Hayashi et al 2009). 
Multiple studies have reported on the benefit of bevacizumab in myopic CNVM, which can lead to more than 15 letters gain of visual acuity in $40 \%$ to $75 \%$ of patients. Those findings have led toward wider use of anti-VEGF agent in these disorders (Ikuno et al. 2009; Gharbiya et al. 2010). Other studies have shown potential benefit of bevacizumab in treatment of CNVM related to angioid streaks and ocular inflammatory diseases (Mansour et al. 2009; Wiegand et al. 2009).

\section{DIABETIC RETINOPATHY}

Diabetic retinopathy is the leading cause of visual loss in the working age group in the United States and other developed countries (Klein et al. 1984). Visual loss from diabetic retinopathy is primarily caused by complications arising from neovascularization in proliferative retinopathy (PDR) or exudation and retinal thickening associated with the development of diabetic macular edema (DME) (Fong et al. 1999).

Laser photocoagulation had remained the standard care for both of these complications for the past 25 years (Ferris et al. 1999). Although there remains a clear role for laser in the treatment of these disorders, recent studies have shown that antiangiogenic approaches combined with either prompt laser or deferred laser result in better visual outcomes for patients with diabetic macular edema than laser alone (Aiello et al. 1994). Long term outcomes of anti-VEGF therapy for the treatment of diabetic macular edema are still being evaluated; however, visual improvement rates are nearly double, and visual loss rates only one third of those with laser alone (Fig. 2). This marked benefit is making anti-VEGF therapy the current primary interventional approach for patients with center involved diabetic macular edema and reduced vision.

\section{ANGIOGENIC MECHANISMS IN PROLIFERATIVE DIABETIC RETINOPATHY}

Metabolic changes in diabetes lead to alterations in the retinal vasculature eventually resulting in reduced perfusion of the retinal tissue and retinal ischemia (Stefansson 2006). This ischemia induces the activity of hypoxia-induced factor (HIF) which up-regulates VEGF expression and the transcription of various other angiogenic factors (Ozaki et al. 1999). In addition to the ischemic stimulus, VEGF expression is also increased by inflammatory mediators (Rojas et al. 2010). The role of VEGF in PDR is supported by studies that reported high concentrations of VEGF in the vitreous of patients with PDR and its excellent correlation with disease activity (Aiello et al. 1994; Adamis et al. 1999). Patients with quiescent PDR had low or undetectable VEGF concentrations and VEGF concentrations were low after successful laser treatment (Aiello et al. 1994). A direct role for VEGF mediation of the neovascular response in PDR was indicated by the fact that vitreous fluids from patients with active PDR were angiogenic in vitro, and this angiogenic stimulus could be blocked using a VEGF specific inhibitor.

Despite the excellent responses to antiVEGF agents observed with certain diseases thus far, there are a substantial percentage of individuals who do not appear to respond robustly to these therapies. This fact, as well as the complex mechanisms regulating in vivo angiogenesis, strongly suggests that there may important factors other than VEGF involved in mediating these conditions. Erythropoietin (EPO) is a potent angiogenic mediator that is thought to act independently of VEGF. Watanabe et al. showed that erythropoietin is present in high concentrations in the vitreous of patients with PDR compared to controls. This study provided the first evidence that EPO acts on the angiogenic pathway independently from VEGF and is more strongly correlated with the presence of PDR than VEGF (Watanabe et al. 2005). Subsequent studies have shown genetic mutations can increase EPO expression and this is associated with increased risk of PDR and related condition in patients and in animals (Tong et al. 2008; Chen et al. 2009; Xiong et al. 2009; Abhary et al. 2010).

Other angiogenic factors are the angiopoietin/Tie-2 system which, as mentioned earlier, modulates the effect of VEGF on endothelial 
M. Al-Latayfeh et al.

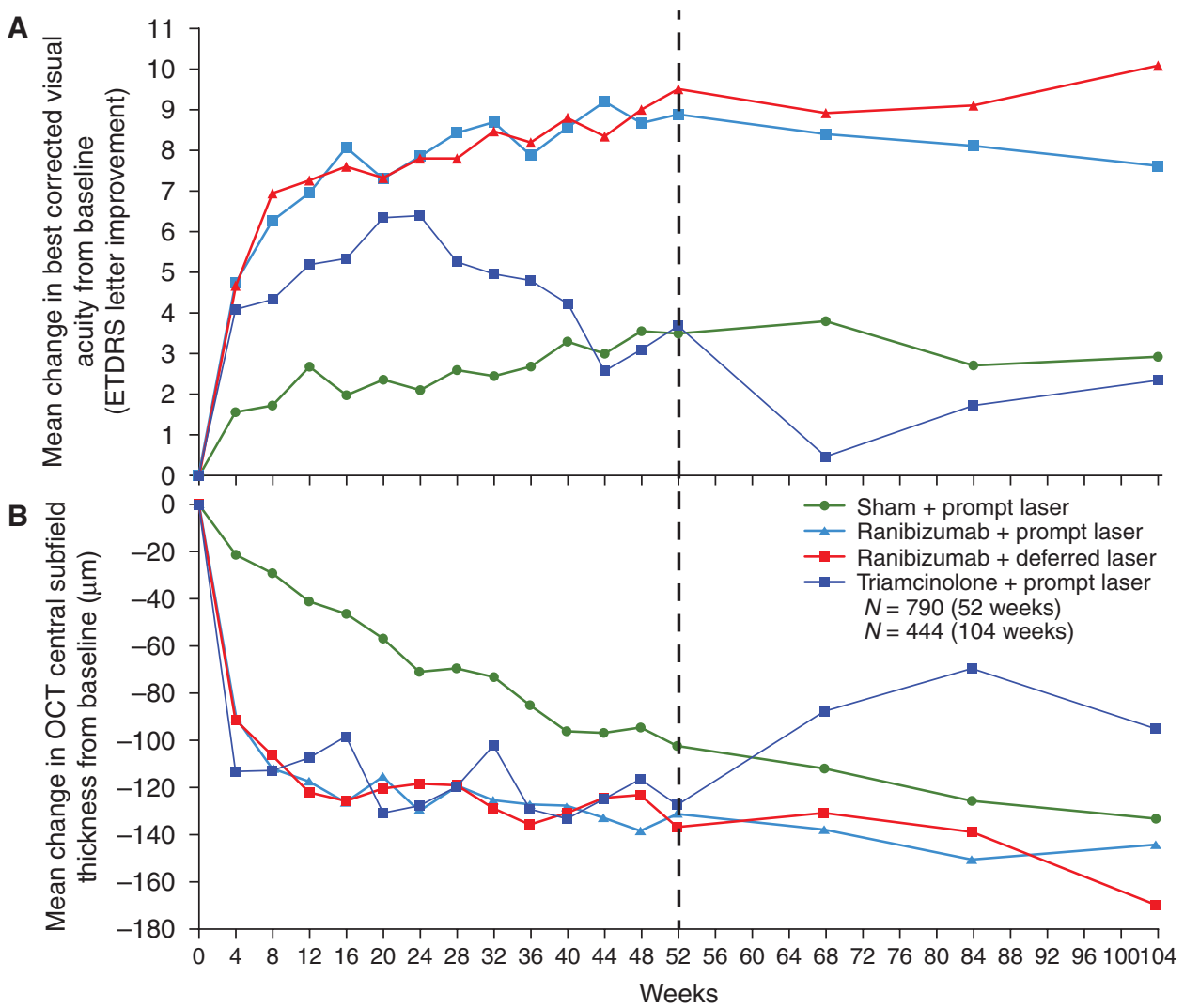

Figure 2. Effect of anti-VEGF therapy on vision and retinal thickening. The DRCR.net has published the 1-year results of a phase III trial that evaluated the safety and efficacy of intravitreal 0.5 -mg ranibizumab or 4 -mg triamcinolone treatments combined with focal/grid laser compared with focal/grid laser alone for the treatment of DME (Elman et al. 2010). Patients were randomized into four treatment arms: $0.5 \mathrm{mg}$ intravitreal ranibizumab with prompt laser treatment $(n=187) ; 0.5 \mathrm{mg}$ intravitreal ranibizumab with laser treatment deferred for at least 24 weeks $(n=188)$; focal/grid laser alone with sham injection $(n=293)$; and $4 \mathrm{mg}$ intravitreal triamcinolone with prompt laser treatment $(n=186)$. (A) At 1 year, the mean change in the visual acuity letter score from baseline was significantly greater in the ranibizumab with prompt laser group $(+9, P=0.001)$ and ranibizumab with deferred laser group $(+9, P=0.001)$, but not in the triamcinolone with prompt laser group $(+4$, $P=0.31)$ compared with the sham injections with prompt laser group $(+3)$. (B) Anti-VEGF treatment causes more favorable reductions in retinal thickness than laser alone, an effect that parallels the overall visual acuity results in the treatment groups. (Figure derived from Elman et al. 2010; reprinted, with permission, from the author.)

cells (Takagi et al. 2003; Cai et al. 2008). Several cytokines also have been shown to have a role in new vessel formation in PDR such as insulinlike growth factor-1 (IGF-1), interleukin-8, placental growth factor, hepatocyte growth factor, platelet-derived growth factor (PDGF), and leptin (Simo et al. 2006). In addition, hyperglycemia results in loss of PDGF survival action thus leading to pericyte apoptosis and diabetic vasculopathy. The probable mechanism involves hyperglycemia-induced activation of protein kinase $\mathrm{C}-\delta(\mathrm{PKC}-\delta)$ which leads to increased expression of a protein tyrosine phosphatase called Src homology-2 domain-containing phosphatase-1 (SHP-1). In addition to possibly mediating hyperglycemic memory, this pathway may be important in early onset of retinopathy via loss of retinal pericytes and 
increase susceptibility of endothelial cells to damage and subsequent hypoxia (Geraldes et al. 2009).

Antiangiogenic factors have also been documented to be present in the eye at various stages of retinopathy (Praidou et al. 2010). Pigment epithelium derived factor (PEDF) has antiangiogenic properties in vitro and is present in the eye. PEDF concentration was found to be lower in patients with diabetes, and in patients with active PDR compared to other retinopathies (Ogata et al. 2001). Animal studies have showed that PEDF down-regulates VEGF and interferes with VEGF-receptor interaction in diabetic retinopathy (Zhang et al. 2006).

\section{ANTIANGIOGENIC THERAPIES FOR PROLIFERATIVE DIABETIC RETINOPATHY}

Panretinal laser photocoagulation remains the standard treatment for PDR. With timely and appropriate application, more than $95 \%$ of the associated severe visual loss can be prevented. However, it is now clear that inactivation of the angiogenic stimulus can at least temporarily induce regression of retinal neovascularization (Fig. 3). Methods for pharmacologically inducing long-term regression of PDR are being studied. Different anti-VEGF agents have shown potential benefit in PDR. Mendrinos et al. (2009) published a case report demonstrating rapid regression of neovascularization after a single injection of pegaptanib, which was sustained for more than 15 months.

Bevacizumab has been shown by Avery et al. (2006) to induce regression of new vessels in PDR as early as 24 hours after injection but with a variable sustained effect ranging between 2 to 11 weeks. Jorge et al. (2006) showed a shortterm resolution of leakage from retinal neovascularization at 6 weeks after a single intravitreal injection of bevacizumab in 15 patients with persistent new vessels despite panretinal laser photocoagulation. At 12 weeks, 14 out of 15 patients showed recurrent leakage but to a lesser extent than at baseline (Jorge et al. 2006). Similar studies have reported similar short term efficacy of bevacizumab in inducing regression of retinal neovascularization (Mirshahi et al.
2008; Tonello et al. 2008; Erdol et al. 2010). Currently, the Diabetic Retinopathy Clinical Research Network (DRCR.net) is conducting two trials: one to study the efficacy of ranibizumab in cases of vitreous hemorrhage caused by PDR, and another to assess the efficacy of adjunctive use of ranibizumab compared to triamcinolone with laser treatment in PDR. The results of these trials will help further define the role of anti-VEGF treatment in the management of diabetic ocular neovascular complications.

\section{ANTIANGIOGENIC AGENTS AS AN ADJUNCT TO VITRECTOMY}

Bevacizumab has shown some benefit as an adjunctive therapy prior to vitrectomy in patients with PDR. Small prospective and retrospective uncontrolled studies have suggested that preoperative bevacizumab facilitates vitrectomy by decreasing intra-operative bleeding and postoperative vitreous hemorrhage, resulting to better visual outcomes (Ahmadieh et al. 2009; Modarres et al. 2009; Oshima et al. 2009; Hernandez-Da Mota and Nunez-Solorio 2010). However, cases of rapid contraction and regression of fibrovascular membranes associated with preoperative intravitreal anti-VEGF agents have been reported to cause progressive tractional detachment particularly in patients who had no previous laser therapy or had a severe ring-like fibrosis threatening the macula (Oshima et al. 2009).

\section{ANTIANGIOGENIC AGENTS IN NEOVASCULAR GLAUCOMA}

Bevacizumab has been shown to be effective in the management of iris neovascularization (NVI) and neovascular glaucoma (NVG). Wakabayashi et al. (2008) published a retrospective analysis of 41 eyes with NVI and NVG treated with intravitreal bevacizumab with mean follow-up of 13.3 months (range 6-22 months). The cohort included patients with NVI alone, open-angle NVG (O-NVG) and closed-angle NVG (C-NVG). One week after the first intravitreal bevacizumab injection 
M. Al-Latayfeh et al.
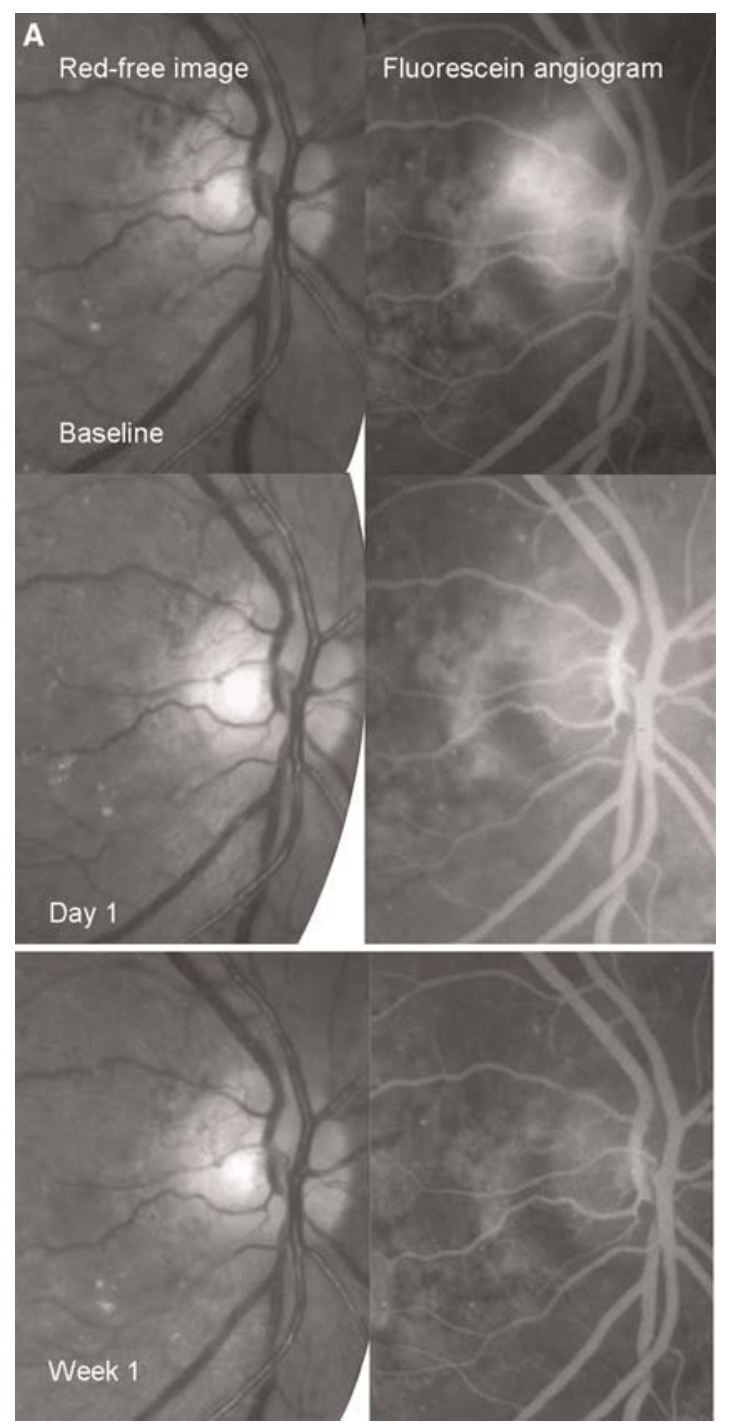

Figure 3. Effect of anti-VEGF agents on retinal neovascularization and macular edema. (A) An intravitreal injection of the anti-VEGF agent bevacizumab has been shown to induce a marked regression of retinal neovascularization beginning as early as 1 day after injection with further regression after 1 week (99). (B) Repeated intravitreal administration of anti-VEGF agents has been shown to reduce the retinal thickening of DME in multiple controlled randomized clinical trials $(11,114,116)$. (A, Derived from Avery et al. 2006; reprinted, with permission, from the author; $B$, courtesy of the Beetham Eye Institute Image Library, Joslin Diabetes Center, Boston, MA.)

NVI regressed in all NVI alone patients. However, $44 \%$ of patients experienced recurrence of the NVI, which again regressed after subsequent repeat injections and laser treatment. For patients with O-NVG, 71\% showed initial normalization of IOP. However, $58 \%$ of the neovascularization recurred within the first 6 months, and $29 \%$ of patients required surgery during the follow-up period. For the C-NVG, intravitreal bevacizumab failed to normalize the IOP in nearly all of the patients and $93 \%$ required surgery to control the IOP during the 


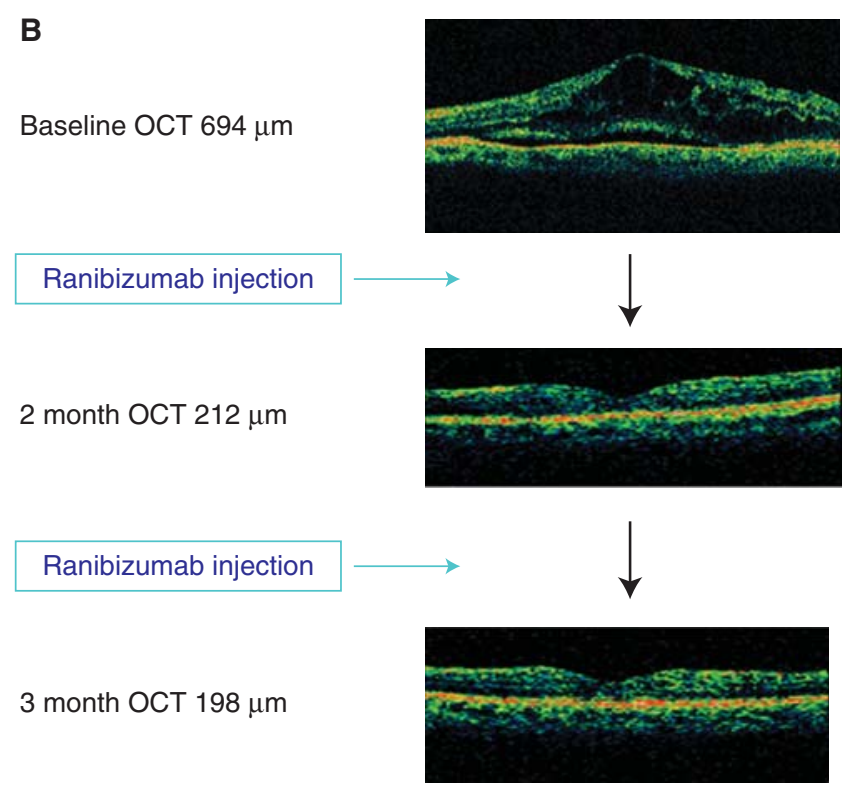

Figure 3. (Continued)

first 2 months of intravitreal bevacizumab treatment despite initial regression of new vessels. The investigators concluded that intravitreal bevacizumab may be effective in the initial stages of iris neovascularization, and it may be a good adjunct for surgical treatment of advanced cases since it may reduce bleeding from the new vessels and potentially may improve surgical outcomes (Wakabayashi et al. 2008). Several other studies showed similar short-term benefits of intravitreal bevacizumab in the management of NVG and NVI (Avery 2006; Davidorf et al. 2006; Brouzas et al. 2009).

Overall, anti-VEGF agents appear very effective in inducing rapid initial regression of ischemia induced ocular neovascularization, but the effect is temporary and requires either additional definitive treatment (such as laser photocoagulation) or development of continuous delivery mechanisms, molecules with longer duration of action or repeated intraocular administration. Large multicenter controlled clinical trials are required to establish the longterm efficacy and determine the best use of antiVEGF agents in the management of PDR and neovascular glaucoma. Furthermore, the safety of continuous or long-term repeated exposure of retinal and choroidal tissue to VEGF inhibition is yet to be established.

\section{ROLE OF ANGIOGENIC FACTORS IN DIABETIC MACULAR EDEMA}

Diabetic macular edema is the leading cause of moderate visual loss among patients with diabetes and can occur at any stage of retinopathy. It results from the accumulation of extracellular fluid within the retinal tissue caused by breakdown of retina-blood barrier and if left untreated ultimately will lead to visual loss. Chronic hyperglycemia leads to alternations in different cellular and molecular pathways leading to the breakdown of endothelial barrier and leakage of intravascular fluids into the extracellular space. Several mechanisms have been proposed to explain the pathogenesis of macular edema including hypoxia, inflammatory mediators, renin-angiotensin system, kallikrein-bradykinin system, protein kinase C (PKC), (Xia et al. 1996; Aiello 2002) and VEGF (Aiello et al. 1997; Ruckman et al. 1998). Several investigators found that VEGF, in particular VEGF-A $\mathrm{A}_{165}$, is a key factor in increasing vascular permeability. VEGF was 
M. Al-Latayfeh et al.

found to induce structural changes in the endothelial tight junctions leading to increased permeability (Antonetti et al. 1999).

The repeated intravitreal administration of anti-VEGF agents have been shown to be more effective than conventional focal/grid laser alone in the treatment of diabetic macular edema (Elman et al. 2010). The Macugen Diabetic Retinopathy Study group recently presented data for the phase III trial for the treatment of DME with pegaptanib (Macugen ${ }^{\circledR}$ ). In this study, 260 patients with DME were randomized to $0.3 \mathrm{mg}$ pegaptanib or a sham injection every 6 weeks for the first year. In the second year, further injection was determined by the investigator based on the specific criteria. Laser treatment can be given starting from week 18 if deemed necessary by the investigator. The primary endpoint was the proportion of patients who experienced an improvement in vision from baseline of two lines, or 10 letters, on the ETDRS eye chart at 1 year. At 1 year, $37 \%$ of pegaptanib patients experience an improvement of 10 letters or more, compared to $20 \%$ of sham-treated patients $(p=0.0047)$. On average, pegaptanib patients gained 5.2 letters of vision at year 1 compared to 1.2 letters for patients receiving sham. At the end of year 2, pegaptanib patients had gained on average 6.1 letters of vision compared to 1.3 letters for patients in the sham arm of the study $(P<$ 0.01) (Sultan et al. 2011).

The DRCR.net conducted a pilot phase II trial to determine the efficacy and safety of intravitreal bevacizumab in the treatment of DME. The study compared five treatment groups: focal laser treatment alone, two groups with two different doses of bevacizumab ( $1.25 \mathrm{mg}$ and $2.5 \mathrm{mg}$ ) at week 0 and 6 , and two additional groups in which $1.25 \mathrm{mg}$ bevacizumab was replaced by sham at week 6 or combined with laser treatment at week 3. The efficacy analysis was performed at 12 weeks and the 24-month safety results were reported as well. Compared with the focal laser-alone group, the bevacizumab groups showed a greater reduction in retinal thickness at 3 weeks but were not significantly different from the control group after that. Compared to the focal-laser alone group, the bevacizumab groups showed a larger improvement in vision with a median improvement in visual acuity of about 1 line at the 3 -week visit, which was sustained through 12 weeks. The results of this pilot study suggested potential benefit of bevacizumab in the treatment DME but definitive efficacy results need a long-term phase III trial (Scott et al. 2007). The READ-2 study (Ranibizumab for Edema of the mAcula in Diabetes) has also reported the phase II results on the efficacy of ranibizumab in DME compared to laser treatment. The study compared three treatment groups: $0.5 \mathrm{mg}$ intravitreal ranibizumab (group 1 ), focal laser photocoagulation (group 2), and combined ranibizumab with focal laser (group 3). The results showed that the ranibizumab treated patients had better visual outcome over 6 months of follow-up. At month 6, the mean gain in best-corrected visual acuity (BCVA) was significantly greater in group 1 $(+7.24$ letters, $p=0.01)$ compared with group 2 ( -0.43 letters), and group 3 ( +3.80 letters) was not statistically different from groups 1 or 2 (Nguyen et al. 2009).

The DRCR.net has published the 1-year results of a phase III trial comparing focal grid laser alone to ranibizumab with prompt or deferred focal/grid laser, or intravitreal triamcinolone with prompt focal/grid laser (Fig. 2) (Elman et al. 2010). It is the largest and most comprehensive randomized controlled trial to date on ranibizumab for the treatment of diabetic macular edema. The patients were randomized into four treatments arms: $0.5 \mathrm{mg}$ intravitreal ranibizumab with prompt laser treatment ( $n=187), 0.5 \mathrm{mg}$ intravitreal ranibizumab with deferred laser treatment $(n=188)$, focal/grid laser alone with sham injection $(n=$ 293) and $4 \mathrm{mg}$ intravitreal triamcinolone with prompt laser treatment $(n=186)$. For the 1-year primary outcome, the mean change in the visual acuity letter score from baseline was significantly greater in the ranibizumab with prompt laser group $(+9, p=0.001)$ and ranibizumab with deferred laser group $(+9, p$ $=0.001)$ but not in the triamcinolone with prompt laser group $(+4, p=0.31)$ as compared with sham injections and prompt laser 
$(+3)$. The results also reflected both a greater proportion of eyes with a substantial improvement of 10 letters or more $(50 \%$ and $47 \%$ vs. $28 \%)$ and 15 letters or more $(30 \%$ and $28 \%$ vs. $15 \%$ ) and a lower proportion of eyes with a substantial worsening of 10 letters or more ( $4 \%$ and $3 \%$ vs. $13 \%)$ and 15 letters or $(2 \%$ and $2 \%$ vs. $8 \%$ ) in the 2 ranibizumab groups compared with the sham + prompt laser group. The study reported that preliminary 2 -year outcomes generally mirrored the 1-year primary outcome results but the 2-year follow-up has only been completed for $57 \%$ of patients. The OCT results comparing the sham/prompt laser and the ranibizumab groups generally paralleled the overall visual acuity results, favoring the ranibizumab groups. The study reported a favorable safety profile for intravitreal ranibizumab with $0.08 \%$ incidence of endophthalmitis and no significant increase in the cardiovascular events compared to controls.

An interesting finding that was noticed by subgroup analysis was a beneficial effect on retinopathy progression (Fig. 4). Both ranibizumab groups showed a trend toward a reduction in 2-level retinopathy progression and an increase in 2-level retinopathy regression, but this was not statistically significant. Using a surrogate of retinopathy progression, both the ranibizumab and triamcinolone groups showed statistically significant reduction in the incidence of vitreous hemorrhage and the need for panretinal laser photocoagulation compared to sham-focal/grid laser group (3\%, $p$ $=0.002$ and $3 \%, p=0.02$, respectively, vs. 8\%) (Elman et al. 2010). Similar effect on retinopathy progression has been seen in other antiVEGF studies.

The first-year results of another phase III trial that compares ranibizumab to laser treatment (Efficacy and Safety of Ranibizumab in Patients With Visual Impairment Due to Diabetic Macular Edema [RESTORE]) have also been reported. The study included 345 patients that were divided into three treatment groups: ranibizumab with sham laser, laser with sham injection, and combined ranibizumab/laser.

\begin{tabular}{|l|c|c|c|}
\hline Change from baseline to 1-year visit & $\begin{array}{c}\text { Sham } \\
\text { + prompt } \\
\text { laser } \\
\text { (total } N=293)\end{array}$ & $\begin{array}{c}\text { Ranibizumab } \\
\text { + prompt laser } \\
\text { or deferred } \\
\text { (total } N=375)\end{array}$ & $\begin{array}{c}\text { Triamcinolone } \\
+ \text { prompt } \\
\text { laser } \\
\text { (total } N=186 \text { ) }\end{array}$ \\
\hline $\begin{array}{l}\text { Baseline severity: Moderately severe } \\
\text { NPDR or better }\end{array}$ & $N=150$ & $N=182$ & $N=80$ \\
\hline Improved by $\geq 2$ levels & $4 \%$ & $25 \%$ & $25 \%$ \\
\hline Worsened by $\geq 2$ levels & $7 \%$ & $3 \%$ & $3 \%$ \\
\hline$P$ value for comparison with Sham & $N=83$ & $N=121$ & $N=70$ \\
\hline $\begin{array}{l}\text { Baseline severity: Severe NPDR or } \\
\text { worse }\end{array}$ & $19 \%$ & $28 \%$ & $13 \%$ \\
\hline Improved by $\geq 2$ levels & $8 \%$ & $1 \%$ & $3 \%$ \\
\hline Worsened by $\geq 2$ levels & $8 \%$ & $P=0.03$ & $P=0.17$ \\
\hline$P$ value for comparison with Sham & & $3 \%$ & $3 \%$ \\
\hline $\begin{array}{l}\text { Reported vitreous hemorrhage OR } \\
\text { received PRP }\end{array}$ & & $P=0.02$ & $P=0.02$ \\
\hline$P$ value for comparison with Sham & & $P=0.08$ & \\
\hline
\end{tabular}

Figure 4. Among patients with severe NPDR or worse, intravitreal injections of anti-VEGF agents has tended to reduce retinopathy progression and an increase retinopathy regression (Elman et al. 2010). A similar association was also observed in the rates of panretinal photocoagulation and vitreous hemorrhage, which are clinical surrogates of retinopathy progression to proliferative disease $(3 \%, P=0.002$ and $3 \%, P=0.02$, respectively, vs. 8\%). (Figure derived from Elman et al. 2010; reprinted, with permission, from the author.) 
M. Al-Latayfeh et al.

The results showed that $37 \%$ of patients treated with ranibizumab $0.5 \mathrm{mg}$ alone, and $43 \%$ of those treated with ranibizumab plus laser therapy, had substantial vision improvement of 10 letters or more compared to $16 \%$ of patients treated with laser alone. The RESTORE study showed that over 1 year, patients treated with ranibizumab plus laser gained 5.9 letters and those treated with ranibizumab gained 6.1 letters whereas, patients receiving laser therapy gained only 0.8 letters compared to baseline (Mitchell et al. 2011).

There are two ongoing phase III trials that are evaluating the efficacy of ranibizumab compared to sham injection (A Study of Ranibizumab Injection in Subjects With Clinically Significant Macular Edema With Center Involvement Secondary to Diabetes Mellitus [RIDE] and A Study of Ranibizumab Injection in Subjects With Clinically Significant Macular Edema With Center Involvement Secondary to Diabetes Mellitus [RISE]). Both studies have enrolled approximately 366 patients and will be completed in 2012.

Other anti-VEGF therapies for macular edema such as VEGF trap have been shown in phase I trials to have encouraging efficacy and good safety profile in DME. The VEGF trap study included five patients given single $4.0 \mathrm{mg}$ of VEGF trap and followed up over 6 weeks. By the end of the follow-up duration, most of the patients showed a trend toward visual acuity improvement and reduction in central foveal thickness (Do et al. 2009).

PKC- $\beta$ inhibitor, ruboxistaurin, given orally, has been shown to delay progression of DME to a sight-threatening stage and may ameliorate edema-associated visual decline in patients with persisting severe DME (PKCDMES Study Group 2007; Davis et al. 2009). PKC-DRS2 group conducted a large multicenter randomized study in which they compared $32 \mathrm{mg}$ of ruboxistaurin given orally to placebo over 36 months. The study included 685 patients from approximately 70 centers. Ruboxistaurin reduced the risk of moderate visual loss to $5.5 \%$ compared to $9.1 \%$ in placebo-treated patients $(p=0.034)$. In addition, mean visual acuity was better in the ruboxistaurin-treated patients after 12 months (15 letters improvement: $4.9 \%$ vs. $2.4 \%$, and 15 -letter worsening: $6.7 \%$ vs. $9.9 \%$ in ruboxistaurin-treated patients relative to placebo, $p=0.005)$. Ruboxistaurin treatment also was associated with less frequent progression of edema to within $100 \mu \mathrm{m}$ of the center $(68 \%$ vs. $50 \%, p=0.003)$. Treatment with ruboxistaurin reduced the risk of initial laser treatment by $26 \%(p=0.008)$ (Aiello et al. 2006). Further clinical studies of ruboxistaurin are ongoing.

\section{ANTIANGIOGENIC TREATMENT FOR RETINAL VEIN OCCLUSION}

Following diabetic retinopathy, retinal vein occlusion (RVO) is the second most common retinal vascular disease that leads to substantial visual loss (Cugati et al. 2006). The ischemic form of RVO is often complicated by macular edema, retinal, and iris neovascularization. RVO is usually classified into central retinal vein occlusion (CRVO) and branch retinal vein occlusion (BRVO) (Hayreh et al. 1994). The main pathophysiologic mechanisms for vision loss in RVO are ischemia or macular edema (The Central Vein Occlusion Study Group 1997). As discussed earlier, ischemia induces the production of various cytokines that will lead to new blood vessels formation and increased capillary permeability. Early studies showed that VEGF is up-regulated in the retinas of patients with RVO (Aiello et al. 1994; Pe're et al. 1998). VEGF and IL-6 also has been found to have high concentrations in patients with RVO (Noma et al. 2010) and are highly correlated with the severity of macular edema (Boyd et al. 2002; Noma et al. 2010). The Standard Care vs. Corticosteroid for Retinal Vein Occlusion (SCORE) study reported outcomes in both CRVO $(1.0 \mathrm{mg}$ or $4.0 \mathrm{mg}$ intravitreal triamcinolone compared with observation) and BRVO (1.0 mg or $4.0 \mathrm{mg}$ intravitreal triamcinolone compared with grid laser). The results of SCORE-CRVO study showed that the visual outcome in patients treated with an intravitreal injection of triamcinolone improved compared to observation alone and that the $1.0 \mathrm{mg}$ triamcinolone 
dose has a superior safety profile compared to the $4.0 \mathrm{mg}$ dose.

In the SCORE-BRVO study, both intravitreal triamcinolone and laser treatment achieved comparable results; however, the rates of adverse events (intraocular pressure elevation and cataracts) were highest with the $4.0 \mathrm{mg}$ dose. The investigators recommended that laser treatment continue to be a component of the standard of care in the treatment of macular edema in patients with BRVO (Ip et al. 2009; Scott et al. 2009). The treatment of macular edema in CRVO and BRVO with intravitreal ranibizumab is based largely on the results of two multicenter controlled clinical trials: The Ranibizumab for the Treatment of Macular Edema after Central Retinal Vein Occlusion Study (CRUISE) and Ranibizumab for the treatment of macular edema following Branch Retinal Vein Occlusion: Evaluation of Efficacy and Safety (BRAVO) study. A total of 392 patients participated in CRUISE and 397 patients participated in BRAVO and were randomized into three treatment groups: $0.3 \mathrm{mg}$ and $0.5 \mathrm{mg}$ ranibizumab and sham group. Patients were given monthly injection for the first 6 months, followed by monthly observation and as needed injections for additional 6 months (Brown et al. 2010; Campochiaro et al. 2010). The 6 months results for BRAVO showed that the percentage of patients in the ranibizumab $0.5 \mathrm{mg}$ group who gained 15 letters or more in BCVA from baseline was $61 \%$, compared with $29 \%$ in the sham group. Patients who received ranibizumab $0.5 \mathrm{mg}$ had a mean gain of 18.3 letters versus 7.3 letters in patients receiving sham injections (Campochiaro et al. 2010). Similarly, in CRUISE, the percentage of patients in the ranibizumab $0.5 \mathrm{mg}$ group who gained 15 letters or more in BCVA from baseline was $48 \%$, compared with $17 \%$ in the sham group. Patients who received ranibizumab $0.5 \mathrm{mg}$ had a mean gain of 14.9 letters versus 0.8 letters for patients receiving sham injections (Brown et al. 2010). The 12 -month results have been presented recently and show persistent benefits of improved visual outcomes throughout the follow-up period (Brown et al. 2011). Bevacizumab also showed similar efficacy in several small and uncontrolled studies for the treatment of macular edema secondary to RVO (Gregori et al. 2008; Prager et al. 2009; Beutel et al. 2010).

\section{CONCLUSIONS}

The introduction of pharmacologic treatments targeting antiangiogenic factors has revolutionized the management of proliferative and exudative complications of the most common sight threatening retinopathies. Based on the results of large multicenter randomized controlled clinical trials, intravitreal injection of anti-VEGF agents are now emerging as part of first line treatment in AMD, RVO, and DME. In addition, they are already considered a valuable adjunct in other conditions such as PDR and NVG with ongoing studies that may further define their role and benefits. Antiangiogenic agents have been used successfully in the treatment of sickle cell retinopathy (Siqueira et al. 2006), retinopathy of prematurity (Altinsoy et al. 2010; Law et al. 2010), radiation retinopathy (Gupta and Muecke 2008) and other similar proliferative retinal vascular diseases. However, the long-term safety and potential toxicity of chronic VEGF inhibition needs to be closely monitored.

A large and rapidly expanding body of angiogenesis research is accumulating from the efforts of multiple investigators around the globe. This information is helping define specific roles for different angiogenic factors and improved treatment modalities and therapeutic regimens. The forthcoming availability of numerous highly specific antiangiogenesis agents and robust clinical trial data demonstrating remarkable efficacy is rapidly revising our current concept of standard care and holds great promise for improved management of these conditions in the near future.

\section{REFERENCES}

\footnotetext{
Abhary S, Burdon KP, Casson RJ, Goggin M, Petrovsky NP, Craig JE. 2010. Association between erythropoietin gene polymorphisms and diabetic retinopathy. Arch Ophthalmol 128: $102-106$.
} 
M. Al-Latayfeh et al.

Abraham P, Yue H, Wilson L. 2010. Randomized, doublemasked, sham-controlled trial of ranibizumab for neovascular age-related macular degeneration: PIER study year 2. Am J Ophthalmol 150: 315-324.

Adamis AP, Aiello LP, D'Amato RA. 1999. Angiogenesis and ophthalmic disease. Angiogenesis 3: 9-14.

Age-Related Eye Disease Study Research Group. 2000. Risk factors associated with age-related macular degeneration. A case-control study in the age-related eye disease study: Age-Related Eye Disease Study Report Number 3. Ophthalmology 107: 2224-2232.

Age-Related Eye Disease Study Research Group. 2001. A randomized, placebo-controlled, clinical trial of highdose supplementation with vitamins $C$ and $E, \beta$ carotene, and zinc for age-related macular degeneration and vision loss: AREDS report no. 8. Arch Ophthalmol 119: 1417-1436.

Ahmadieh H, Shoeibi N, Entezari M, Monshizadeh R. 2009. Intravitreal bevacizumab for prevention of early postvitrectomy hemorrhage in diabetic patients: A randomized clinical trial. Ophthalmology 116: 1943-1948.

Aiello LP. 2002. The potential role of PKC $\beta$ in diabetic retinopathy and macular edema. Surv Ophthalmol 47 (Suppl 2): S263-S269.

Aiello LP, Avery RL, Arrigg PG, Keyt BA, Jampel HD, Shah ST, Pasquale LR, Thieme H, Iwamoto MA, Park JE. 1994. Vascular endothelial growth factor in ocular fluid of patients with diabetic retinopathy and other retinal disorders. N Engl J Med 331: 1480-1487.

Aiello LP, Pierce EA, Foley ED, Takagi H, Chen H, Riddle L, Ferrara N, King GL, Smith LE. 1995. Suppression of retinal neovascularization in vivo by inhibition of vascular endothelial growth factor (VEGF) using soluble VEGF-receptor chimeric proteins. Proc Natl Acad Sci 92: 10457-10461.

Aiello LP, Bursell SE, Clermont A, Duh E, Ishii H, Takagi C, Mori F, Ciulla TA, Ways K, Jirousek M, King GL, et al. 1997. Vascular endothelial growth factor-induced retinal permeability is mediated by protein kinase $\mathrm{C}$ in vivo and suppressed by an orally effective $\beta$-isoform-selective inhibitor. Diabetes 46: 1473-1480.

Aiello LP, Davis MD, Girach A, Kles KA, Milton RC, Sheetz MJ, Vignati L, Zhi XE. 2006. Effect of ruboxistaurin on visual loss in patients with diabetic retinopathy. Ophthalmology 113: 2221-2230.

Aljada A, O'Connor L, Fu YY, Mousa SA. 2008. PPAR $\gamma$ ligands, rosiglitazone and pioglitazone, inhibit bFGFand VEGF-mediated angiogenesis. Angiogenesis 11: 361-367.

Altinsoy HI, Mutlu FM, Gungor R, Sarici SU. 2010. Combination of laser photocoagulation and intravitreal bevacizumab in aggressive posterior retinopathy of prematurity. Ophthalmic Surg Lasers Imaging 9: 1-5.

Andreoli CM, Miller JW. 2007. Anti-vascular endothelial growth factor therapy for ocular neovascular disease. Curr Opin Ophthalmol 18: 502-508.

Antonetti DA, Barber AJ, Hollinger LA, Wolpert EB, Gardner TW. 1999. Vascular endothelial growth factor induces rapid phosphorylation of tight junction proteins occludin and zonula occluden 1. A potential mechanism for vascular permeability in diabetic retinopathy and tumors. J Biol Chem 274: 23463-23467.
Asahara T, Chen D, Takahashi T, Fujikawa K, Kearney M, Magner M, Yancopoulos GD, Isner JM. 1998. Tie2 receptor ligands, angiopoietin-1 and angiopoietin-2, modulate VEGF-induced postnatal neovascularization. Circ Res 83: 233-240.

Avery RL. 2006. Regression of retinal and iris neovascularization after intravitreal bevacizumab. (Avastin) treatment. Retina 26: 352-354.

Avery RL, Pearlman J, Pieramici DJ, Rabena MD, Castellarin AA, Nasir MA, Giust MJ, Wendel R, Patel A. 2006. Intravitreal bevacizumab (Avastin) in the treatment of proliferative diabetic retinopathy. Ophthalmology 113: 1695.

Bashshur ZF, Haddad ZA, Schakal AR, Jaafar RF, Saad A, Noureddin BN. 2009. Intravitreal bevacizumab for treatment of neovascular age-related macular degeneration: The second year of a prospective study. Am J Ophthalmol 148: 59-65.

Beatty S, Koh H, Phil M, Henson D, Boulton M. 2000. The role of oxidative stress in the pathogenesis of age-related macular degeneration. Surv Ophthalmol 45: 115-134.

Beutel J, Ziemssen F, Luke M, Partsch M, Bartz-Schmidt KU, Gelisken F. 2010. Intravitreal bevacizumab treatment of macular edema in central retinal vein occlusion: Oneyear results. Int Ophthalmol 30: 15-22.

Boyd SR, Zachary I, Chakravarthy U, Allen GJ, Wisdom GB, Cree IA, Martin JF, Hykin PG. 2002. Correlation of increased vascular endothelial growth factor with neovascularization and permeability in ischemic central vein occlusion. Arch Ophthalmol 120: 1644-1650.

Boyer DS, Heier JS, Brown DM, Francom SF, Ianchulev T, Rubio RG. 2009. A phase IIIb study to evaluate the safety of ranibizumab in subjects with neovascular age-related macular degeneration. Ophthalmology 116: 1731-1739.

Bressler NM. 2001. Treatment of age-related macular degeneration with photodynamic therapy: Photodynamic therapy of subfoveal choroidal neovascularization in age-related macular degeneration with verteporfin: twoyear results of 2 randomized clinical trials-tap report 2 . Arch Ophthalmol 119: 198-207.

Bressler NM, Bressler SB, Fine SL. 1988. Age-related macular degeneration. Surv Ophthalmol 32: 375-413.

Brouzas D, Charakidas A, Moschos M, Koutsandrea C, Apostolopoulos M, Baltatzis S. 2009. Bevacizumab (Avastin) for the management of anterior chamber neovascularization and neovascular glaucoma. Clin Ophthalmol 3: 685-688.

Brown DM, Michels M, Kaiser PK, Heier JS, Sy JP, Ianchulev T. 2009. ANCHOR Study Group: Ranibizumab versus verteporfin photodynamic therapy for neovascular age-related macular degeneration: Two-year results of the ANCHOR study. Ophthalmology 116: 57-65.

Brown DM, Campochiaro PA, Singh RP, Li Z, Gray S, Saroj N, Rundle AC, Rubio RG, Murahashi WY. 2010. Ranibizumab for macular edema following central retinal vein occlusion: six-month primary end point results of a phase III study. Ophthalmology 117: 1124-1133.

Brown DM, Campochiaro PA, Bhisitkul RB, Ho AC, Gray S, Saroj N, Adamis AP, Rubio RG, Murahashi WY. 2011. Sustained benefits from ranibizumab for macular edema following branch retinal vein occlusion: 12-Month outcomes of a phase III study. Ophthalmology 118: $1594-1602$. 
Brown DM, Heier JS, Ciulla T, Benz M, Abraham P, Yancopoulos G, Stahl N, Ingerman A, Vitti R, Berliner AJ, et al. 2011. Primary endpoint results of a phase II study of vascular endothelial growth factor trap-eye in wet age-related macular degeneration. Ophthalmology 118: 1089-1097.

Cai J, Kehoe O, Smith GM, Hykin P, Boulton ME. 2008. The angiopoietin/Tie-2 system regulates pericyte survival and recruitment in diabetic retinopathy. Invest Ophthalmol Vis Sci 49: 2163-2171.

Campochiaro PA, Heier JS, Feiner L, Gray S, Saroj N, Rundle AC, Murahashi WY, Rubio RG. 2010. Ranibizumab for macular edema following branch retinal vein occlusion: Six-month primary end point results of a phase III study. Ophthalmology 117: 1102-1112.

Carlini RG, Reyes AA, Rothstein M. 1995. Recombinant human erythropoietin stimulates angiogenesis in vitro. Kidney Int 47: 740-745.

CATT Research Group, Martin DF, Maguire MG, Ying GS, Grunwald JE, Fine SL, Jaffe GJ. 2011. Ranibizumab and bevacizumab for neovascular age-related macular degeneration. N Engl J Med 364: 1897-1908.

Chen J, Connor KM, Aderman CM, Willett KL, Aspegren OP, Smith LE. 2009. Suppression of retinal neovascularization by erythropoietin siRNA in a mouse model of proliferative retinopathy. Invest Ophthalmol Vis Sci 50: $1329-1335$.

Chew EY, Ferris FL III, Csaky KG, Murphy RP, Agron E, Thompson DJ, Reed GF, Schachat AP. 2003. The longterm effects of laser photocoagulation treatment in patients with diabetic retinopathy: The early treatment diabetic retinopathy follow-up study. Ophthalmology 110: $1683-1689$.

Clemons TE, Milton RC, Klein R, Seddon JM, Ferris FL III 2005. Age-Related Eye Disease Study Research Group: Risk factors for the incidence of Advanced Age-Related Macular Degeneration in the Age-Related Eye Disease Study (AREDS) AREDS report no. 19. Ophthalmology 112: $533-539$.

Congdon N, O'Colmain B, Klaver CC, Klein R, Munoz B, Friedman DS, Kempen J, Taylor HR, Mitchell P. 2004. Eye Diseases Prevalence Research Group: Causes and prevalence of visual impairment among adults in the United States. Arch Ophthalmol 122: 477-485.

Cugati S, Wang JJ, Rochtchina E, Mitchell P. 2006. Ten-year incidence of retinal vein occlusion in an older population: The Blue Mountains Eye Study. Arch Ophthalmol 124: 726-732.

Davidorf FH, Mouser JG, Derick RJ. 2006. Rapid improvement of rubeosis iridis from a single bevacizumab (Avastin) injection. Retina 26: 354-356.

Davis MD, Sheetz MJ, Aiello LP, Milton RC, Danis RP, Zhi X, Girach A, Jimenez MC, Vignati L. 2009. Effect of ruboxistaurin on the visual acuity decline associated with longstanding diabetic macular edema. Invest Ophthalmol Vis Sci 50: 1-4.

Do DV, Nguyen QD, Shah SM, Browning DJ, Haller JA, Chu K, Yang K, Cedarbaum JM, Vitti RL, Ingerman A, Campochiaro PA. 2009. An exploratory study of the safety, tolerability and bioactivity of a single intravitreal injection of vascular endothelial growth factor Trap-Eye in patients with diabetic macular oedema. Br J Ophthalmol 93: 144-149.

Donoso LA, Kim D, Frost A, Callahan A, Hageman G. 2006. The role of inflammation in the pathogenesis of age-related macular degeneration. Surv Ophthalmol 51: $137-152$.

Dor Y, Porat R, Keshet E. 2001. Vascular endothelial growth factor and vascular adjustments to perturbations in oxygen homeostasis. Am J Physiol Cell Physiol 280: C1367-C1374.

Edwards AO, Ritter RIII, Abel KJ, Manning A, Panhuysen C, Farrer LA. 2005. Complement factor H polymorphism and age-related macular degeneration. Science 308: 421-424.

Elman MJ, Aiello LP, Beck RW, Bressler NM, Bressler SB, Edwards AR, Ferris FL, Friedman SM, Glassman AR, Miller KM, Sun JK, et al. 2010. Randomized trial evaluating ranibizumab plus prompt or deferred laser or triamcinolone plus prompt laser for diabetic macular edema. Ophthalmology 117: 1064-1077.

Erdol H, Turk A, Akyol N, Imamoglu HI. 2010. The results of intravitreal bevacizumab injections for persistent neovascularizations in proliferative diabetic retinopathy after photocoagulation therapy. Retina 30: 570-577.

Ferrara N. 2004. Vascular endothelial growth factor: Basic science and clinical progress. Endocr Rev 25: 581-611.

Ferrara N, Henzel WJ. 1989. Pituitary follicular cells secrete a novel heparin-binding growth factor specific for vascular endothelial cells. Biochem Biophys Res Commun 161: 851-858.

Ferrara N, Hillan KJ, Novotny W. 2005. Bevacizumab (Avastin), a humanized anti-VEGF monoclonal antibody for cancer therapy. Biochem Biophys Res Commun 333: $328-335$.

Ferris FLIII, Davis MD, Aiello LM. 1999. Treatment of diabetic retinopathy. N Engl J Med 341: 667-678.

Fong DS, Ferris FLIII, Davis MD, Chew EY. 1999. Causes of severe visual loss in the early treatment diabetic retinopathy study: ETDRS report no. 24. Early Treatment Diabetic Retinopathy Study Research Group. Am J Ophthalmol 127: 137-141.

Gao BB, Clermont A, Rook S, Fonda SJ, Srinivasan VJ, Wojtkowski M, Fujimoto JG, Avery RL, Arrigg PG, Bursell SE, et al. 2007. Extracellular carbonic anhydrase mediates hemorrhagic retinal and cerebral vascular permeability through prekallikrein activation. Nat Med 13: 181-188.

Geraldes P, Hiraoka-Yamamoto J, Matsumoto M, Clermont A, Leitges M, Marette A, Aiello LP, Kern TS, King GL. 2009 . Activation of PKC- $\delta$ and SHP-1 by hyperglycemia causes vascular cell apoptosis and diabetic retinopathy. Nat Med 15: 1298-1306.

Gharbiya M, Giustolisi R, Allievi F, Fantozzi N, Mazzeo L, Scavella V, Gabrieli CB. 2010. Choroidal neovascularization in pathologic myopia: Intravitreal ranibizumab versus bevacizumab-A randomized controlled trial. Am J Ophthalmol 149: 458-464.

Girach A, Aiello LP, Milton RC, Davis MD, Danis RP, Zhi X, Sheetz MJ, Vignati L, PKC-DRS2 Study Group. 2009. Sustained moderate visual loss as a predictive end point for visual loss in non-proliferative diabetic retinopathy. Eye (Lond) 23: 209-214. 
M. Al-Latayfeh et al.

Gragoudas ES, Adamis AP, Cunningham ET Jr, Feinsod M, Guyer DR. 2004. VEGF Inhibition Study in Ocular Neovascularization Clinical Trial Group: Pegaptanib for neovascular age-related macular degeneration. $N$ Engl J Med 351: 2805-2816.

Gregori NZ, Gaitan J, Rosenfeld PJ, Puliafito CA, Feuer W, Flynn HW, Berrocal AM, Al Attar L, Dubovy S, Smiddy WE, et al. 2008. Long-term safety and efficacy of intravitreal bevacizumab (Avastin) for the management of central retinal vein occlusion. Retina 28: 1325-1337.

Gupta A, Muecke JS. 2008. Treatment of radiation maculopathy with intravitreal injection of bevacizumab (Avastin). Retina 28: 964-968.

Hayashi K, Ohno-Matsui K, Teramukai S, Shimada N, Moriyama M, Hayashi W, Yoshida T, Tokoro T, Mochizuki M. 2009. Comparison of visual outcome and regression pattern of myopic choroidal neovascularization after intravitreal bevacizumab or after photodynamic therapy. $A m$ J Ophthalmol 148: 396-408.

Hayreh SS, Zimmerman MB, Podhajsky P. 1994. Incidence of various types of retinal vein occlusion and their recurrence and demographic characteristics. Am J Ophthalmol 117: 429-441.

Heier JS, Boyer D, Nguyen QD, Marcus D, Roth DB, Yancopoulos $\mathrm{G}$, Stahl N, Ingerman A, Vitti R, Berliner AJ, et al. 2011. The 1-year results of CLEAR-IT 2, a phase 2 study of vascular endothelial growth factor trap-eye dosed as-needed after 12-week fixed dosing. Ophthalmology 118: $1098-1106$.

Henkind P, Wise GN. 1974. Retinal neovascularization, collaterals, and vascular shunts. $\mathrm{Br} J$ Ophthalmol 58: 413-422.

Hernandez-Da Mota SE. 2010. Nunez-Solorio SM: Experience with intravitreal bevacizumab as a preoperative adjunct in 23-G vitrectomy for advanced proliferative diabetic retinopathy. Eur J Ophthalmol 20: 1047-1052.

Holash J, Davis S, Papadopoulos N, Croll SD, Ho L, Russell M, Boland P, Leidich R, Hylton D, Burova E, et al. 2002. VEGF-trap: A VEGF blocker with potent antitumor effects. Proc Natl Acad Sci 99: 11393-11398.

Houck KA, Ferrara N, Winer J, Cachianes G, Li B, Leung DW. 1991. The vascular endothelial growth factor family: Identification of a fourth molecular species and characterization of alternative splicing of RNA. Mol Endocrinol 5: $1806-1814$.

Ikuno Y, Sayanagi K, Soga K, Sawa M, Tsujikawa M, Gomi F, Tano Y. 2009. Intravitreal bevacizumab for choroidal neovascularization attributable to pathological myopia: oneyear results. Am J Ophthalmol 147: 94-100.

Ip MS, Scott IU, VanVeldhuisen PC, Oden NL, Blodi BA, Fisher M, Singerman LJ, Tolentino M, Chan CK, Gonzalez VH. 2009. A randomized trial comparing the efficacy and safety of intravitreal triamcinolone with observation to treat vision loss associated with macular edema secondary to central retinal vein occlusion: The Standard Care vs Corticosteroid for Retinal Vein Occlusion (SCORE) study report 5. Arch Ophthalmol 127: 1101-1114.

Jager RD, Mieler WF, Miller JW. 2008. Age-related macular degeneration. N Engl J Med 358: 2606-2617.

Jelkmann W. 1992. Erythropoietin: Structure, control of production, and function. Physiol Rev 72: 449-489.
Jorge R, Costa RA, Calucci D, Cintra LP, Scott IU. 2006. Intravitreal bevacizumab (Avastin) for persistent new vessels in diabetic retinopathy (IBEPE study). Retina 26: 1006-1013.

Kaiser PK. 2006. Antivascular endothelial growth factor agents and their development: Therapeutic implications in ocular diseases. Am J Ophthalmol 142: 660-668.

Klein R, Klein BE, Moss SE. 1984. Visual impairment in diabetes. Ophthalmology 91: 1-9.

Klein R, Peto T, Bird A, Vannewkirk MR. 2004. The epidemiology of age-related macular degeneration. Am J Ophthalmol 137: 486-495.

Law JC, Recchia FM, Morrison DG, Donahue SP, Estes RL. 2010. Intravitreal bevacizumab as adjunctive treatment for retinopathy of prematurity. JAAPOS 14: 6-10.

Macular Photocoagulation Study Group. 1991. Laser photocoagulation of subfoveal recurrent neovascular lesions in age-related macular degeneration. Results of a randomized clinical trial. Arch Ophthalmol 109: 12321241.

Macular Photocoagulation Study Group. 1993. Laser photocoagulation of subfoveal neovascular lesions of age-related macular degeneration. Updated findings from two clinical trials. Arch Ophthalmol 111: $1200-$ 1209.

Maisonpierre PC, Suri C, Jones PF, Bartunkova S, Wiegand SJ, Radziejewski C, Compton D, McClain J, Aldrich TH, Papadopoulos N, et al. 1997. Angiopoietin-2, a natural antagonist for Tie2 that disrupts in vivo angiogenesis. Science 277: 55-60.

Mansour AM, Arevalo JF, Ziemssen F, Mehio-Sibai A, Mackensen F, Adan A, Chan WM, Ness T, Banker AS, Dodwell D, et al. 2009. Long-term visual outcomes of intravitreal bevacizumab in inflammatory ocular neovascularization. Am J Ophthalmol 148: 310-316.

Mathews MK, Merges C, McLeod DS, Lutty GA. 1997. Vascular endothelial growth factor and vascular permeability changes in human diabetic retinopathy. Invest Ophthalmol Vis Sci 38: 2729-2741.

McIntosh RL, Rogers SL, Lim L, Cheung N, Wang JJ, Mitchell P, Kowalski JW, Nguyen HP, Wong TY. 2010. Natural history of central retinal vein occlusion: An evidencebased systematic review. Ophthalmology 117: 1113-1123.

Mendrinos E, Donati G, Pournaras CJ. 2009. Rapid and persistent regression of severe new vessels on the disc in proliferative diabetic retinopathy after a single intravitreal injection of pegaptanib. Acta Ophthalmol 87: 683-684.

Miller JW, Adamis AP, Shima DT, D'Amore PA, Moulton RS, O'Reilly MS, Folkman J, Dvorak HF, Brown LF, Berse B, et al. 1994. Vascular endothelial growth factor/vascular permeability factor is temporally and spacially correlated with ocular angiogenesis in a primate model. Am J Pathol 145: $574-584$.

Miller JW, Schmidt-Erfurth U, Sickenberg M, Pournaras CJ, Laqua H, Barbazetto I, Zografos L, Piguet B, Donati G, Lane AM, et al. 1999. Photodynamic therapy with verteporfin for choroidal neovascularization caused by age-related macular degeneration: Results of a single treatment in a phase 1 and 2 study. Arch Ophthalmol 117: 1161-1173.

Mirshahi A, Roohipoor R, Lashay A, Mohammadi SF, Abdoallahi A, Faghihi H. 2008. Bevacizumab-augmented 
retinal laser photocoagulation in proliferative diabetic retinopathy: A randomized double-masked clinical trial. Eur J Ophthalmol 18: 263-269.

Mitchell P, Bandello F, Schmidt-Erfurth U, Lang GE, Massin P, Schlingemann RO, Sutter F, Simader C, Burian G, Gerstner O, et al. 2011. The RESTORE study: Ranibizumab monotherapy or combined with laser versus laser monotherapy for diabetic macular edema. Ophthalmology 118: 615-625.

Modarres M, Nazari H, Falavarjani KG, Naseripour M, Hashemi M, Parvaresh MM. 2009. Intravitreal injection of bevacizumab before vitrectomy for proliferative diabetic retinopathy. Eur J Ophthalmol 19: 848-852.

Murata T, Ishibashi T, Khalil A, Hata Y, Yoshikawa H, Inomata H. 1995. Vascular endothelial growth factor plays a role in hyperpermeability of diabetic retinal vessels. Ophthalmic Res 27: 48-52.

Nguyen QD, Shah SM, Browning DJ, Hudson H, Sonkin P, Hariprasad SM, Kaiser P, Slakter JS, Haller J, Do DV, et al. 2009. A phase I study of intravitreal vascular endothelial growth factor trap-eye in patients with neovascular age-related macular degeneration. Ophthalmology 116: 2141-2148.

Nguyen QD, Shah SM, Heier JS, Do DV, Lim J, Boyer D, Abraham P. Campochiaro PA. 2009. Primary end point (six months) results of the Ranibizumab for Edema of the Macula in Diabetes (READ-2) study. Ophthalmology 116: $2175-2181$.

Noma H, Funatsu H, Mimura T, Harino S, Hori S. 2010. Aqueous humor levels of vasoactive molecules correlate with vitreous levels and macular edema in central retinal vein occlusion. Eur J Ophthalmol 20: 402-409.

Nowak JZ. 2006. Age-related macular degeneration (AMD): Pathogenesis and therapy. Pharmacol Rep 58: 353-363.

Ogata N, Tombran-Tink J, Nishikawa M, Nishimura T, Mitsuma Y, Sakamoto T, Matsumura M. 2001. Pigment epithelium-derived factor in the vitreous is low in diabetic retinopathy and high in rhegmatogenous retinal detachment. Am J Opthalmol 132: 378-382.

Oshima Y, Shima C, Wakabayashi T, Kusaka S, Shiraga F, Ohji M, Tano Y. 2009. Microincision vitrectomy surgery and intravitreal bevacizumab as a surgical adjunct to treat diabetic traction retinal detachment. Ophthalmology 116: 927-938.

Ozaki H, Yu AY, Della N, Ozaki K, Luna JD, Yamada H, Hackett SF, Okamoto N, Zack DJ, Semenza GL, Campochiaro PA. 1999. Hypoxia inducible factor- $1 \alpha$ is increased in ischemic retina: Temporal and spatial correlation with VEGF expression. Invest Ophthalmol Vis Sci 40: 182-189.

Panigrahy D, Singer S, Shen LQ, Butterfield CE, Freedman DA, Chen EJ, Moses MA, Kilroy S, Duensing S, Fletcher C, et al. 2002. PPARy ligands inhibit primary tumor growth and metastasis by inhibiting angiogenesis. J Clin Invest 110: 923-932.

Pe'er J, Folberg R, Itin A, Gnessin H, Hemo I, Keshet E. 1998. Vascular endothelial growth factor upregulation in human central retinal vein occlusion. Ophthalmology 105: 412-416.

Phipps JA, Clermont AC, Sinha S, Chilcote TJ, Bursell SE, Feener EP. 2009. Plasma kallikrein mediates angiotensin II type 1 receptor-stimulated retinal vascular permeability. Hypertension 53: 175-181.
Pierce EA, Avery RL, Foley ED, Aiello LP, Smith LE. 1995. Vascular endothelial growth factor/vascular permeability factor expression in a mouse model of retinal neovascularization. Proc Natl Acad Sci 92: 905-909.

PKC DRS, Aiello LP, Davis MD, Girach A, Kles KA, Milton RC, Sheetz MJ, Vignati L, Zhi XE. 2006. Effect of ruboxistaurin on visual loss in patients with diabetic retinopathy. Ophthalmology 113: 2221-2230.

PKC-DRS Study Group. 2005. The effect of ruboxistaurin on visual loss in patients with moderately severe to very severe nonproliferative diabetic retinopathy: Initial results of the Protein Kinase C $\beta$ Inhibitor Diabetic Retinopathy study (PKC-DRS) multicenter randomized clinical trial. Diabetes 54: 2188-2197.

PKC-DMES Study Group. 2007. Effect of ruboxistaurin in patients with diabetic macular edema: Thirty-month results of the randomized PKC-DMES clinical trial. Arch Ophthalmol 125: 318-324.

Prager F, Michels S, Kriechbaum K, Georgopoulos M, Funk M, Geitzenauer W, Polak K. Schmidt-Erfurth U. 2009. Intravitreal bevacizumab (Avastin) for macular oedema secondary to retinal vein occlusion: 12 -month results of a prospective clinical trial. Br J Ophthalmol 93: 452-456.

Praidou A, Androudi S, Brazitikos P, Karakiulakis G, Papakonstantinou E, Dimitrakos S. 2010. Angiogenic growth factors and their inhibitors in diabetic retinopathy. Curr Diabetes Rev 6: 304-312.

Regillo CD, Brown DM, Abraham P, Yue H, Ianchulev T, Schneider S, Shams N. 2008. Randomized, doublemasked, sham-controlled trial of ranibizumab for neovascular age-related macular degeneration: PIER Study year 1. Am J Ophthalmol 145: 239-248.

Ribatti D, Presta M, Vacca A, Ria R, Giuliani R, Dell'Era P, Nico B, Roncali L, Dammacco F. 1999. Human erythropoietin induces a pro-angiogenic phenotype in cultured endothelial cells and stimulates neovascularization in vivo. Blood 93: 2627-2636.

Rogers SL, McIntosh RL, Lim L, Mitchell P, Cheung N, Kowalski JW, Nguyen HP, Wang JJ, Wong TY. 2010. Natural history of branch retinal vein occlusion: An evidence-based systematic review. Ophthalmology 117: 1094-1101.

Rojas M, Zhang W, Lee DL, Romero MJ, Nguyen DT, Al Shabrawey M, Tsai NT, Liou GI, Brands MW, Caldwell RW, Caldwell RB. 2010. Role of IL-6 in angiotensin II-induced retinal vascular inflammation. Invest $\mathrm{Oph}$ thalmol Vis Sci 51: 1709-1718.

Rosenfeld PJ, Moshfeghi AA, Puliafito CA. 2005a. Optical coherence tomography findings after an intravitreal injection of bevacizumab (avastin) for neovascular age-related macular degeneration. Ophthalmic Surg Lasers Imaging 36: 331-335.

Rosenfeld PJ, Schwartz SD, Blumenkranz MS, Miller JW, Haller JA, Reimann JD, Greene WL, Shams N. 2005b. Maximum tolerated dose of a humanized anti-vascular endothelial growth factor antibody fragment for treating neovascular age-related macular degeneration. Ophthalmology 112: 1048-1053.

Rosenfeld PJ, Brown DM, Heier JS, Boyer DS, Kaiser PK, Chung CY, Kim RY. 2006. MARINA Study Group: Ranibizumab for neovascular age-related macular degeneration. N Engl J Med 355: 1419-1431. 
M. Al-Latayfeh et al.

Ruckman J, Green LS, Beeson J, Waugh S, Gillette WL, Henninger DD, Claesson-Welsh L, Janjic N. 1998. 2'-Fluoropyrimidine RNA-based aptamers to the 165 -amino acid form of vascular endothelial growth factor. (VEGF165). Inhibition of receptor binding and VEGF-induced vascular permeability through interactions requiring the exon 7-encoded domain. J Biol Chem 273: 20556-20567.

Scott IU, Edwards AR, Beck RW, Bressler NM, Chan CK, Elman MJ, Friedman SM, Greven CM, Maturi RK, Pieramici DJ, et al. 2007. A phase II randomized clinical trial of intravitreal bevacizumab for diabetic macular edema. Ophthalmology 114: 1860-1867.

Scott IU, Ip MS, VanVeldhuisen PC, Oden NL, Blodi BA, Fisher M, Chan CK, Gonzalez VH, Singerman LJ, Tolentino M. 2009. A randomized trial comparing the efficacy and safety of intravitreal triamcinolone with standard care to treat vision loss associated with macular Edema secondary to branch retinal vein occlusion: The Standard Care vs Corticosteroid for Retinal Vein Occlusion (SCORE) study report 6. Arch Ophthalmol 127: $1115-1128$.

Semenza GL. 2003. Angiogenesis in ischemic and neoplastic disorders. Annu Rev Med 54: 17-28.

Shen LQ, Child A, Weber GM, Folkman J, Aiello LP. 2008. Rosiglitazone and delayed onset of proliferative diabetic retinopathy. Arch Ophthalmol 126: 793-799.

Simo R, Carrasco E, Garcia-Ramirez M, Hernandez C. 2006. Angiogenic and antiangiogenic factors in proliferative diabetic retinopathy. Curr Diabetes Rev 2: 71-98.

Singerman L. 2009. Combination therapy using the small interfering RNA bevasiranib. Retina 29: S49-S50.

Siqueira RC, Costa RA, Scott IU, Cintra LP, Jorge R. 2006. Intravitreal bevacizumab (Avastin) injection associated with regression of retinal neovascularization caused by sickle cell retinopathy. Acta Ophthalmol Scand 84: 834-835.

Stefansson E. 2006. Ocular oxygenation and the treatment of diabetic retinopathy. Surv Ophthalmol 51: 364-380.

Sultan MB, Zhou D, Loftus J, Dombi T, Ice KS. 2011. Study Group: A phase 2/3, multicenter, randomized, doublemasked, 2-year trial of pegaptanib sodium for the treatment of diabetic macular edema. Ophthalmology 118: 1107-1118.

Sun JK, Aiello LP, Miller JW. 2008. Proliferative diabetic retinopathy. In Principles and practice of ophthalmology, 3rd ed. (ed. Albert DM), pp. 1807-1827. W.B. Saunders Co., Philadelphia.

Suri C, Jones PF, Patan S, Bartunkova S, Maisonpierre PC, Davis S, Sato TN, Yancopoulos GD. 1996. Requisite role of angiopoietin-1, a ligand for the TIE2 receptor, during embryonic angiogenesis. Cell 87: 1171-1180.

Takagi H, Koyama S, Seike H, Oh H, Otani A, Matsumura M, Honda Y. 2003. Potential role of the angiopoietin/ tie2 system in ischemia-induced retinal neovascularization. Invest Ophthalmol Vis Sci 44: 393-402.

Takahashi K, Saishin Y, Saishin Y, King AG, Levin R. 2009. Campochiaro PA: Suppression and regression of choroidal neovascularization by the multitargeted kinase inhibitor pazopanib. Arch Ophthalmol 127: 494-499.

The Central Vein Occlusion Study Group. 1997. Natural history and clinical management of central retinal vein occlusion. Arch Ophthalmol 115: 486-491.

Tischer E, Mitchell R, Hartman T, Silva M, Gospodarowicz D, Fiddes JC, Abraham JA. 1991. The human gene for vascular endothelial growth factor. Multiple protein forms are encoded through alternative exon splicing. $J$ Biol Chem 266: 1 11947-11954.

Tonello M, Costa RA, Almeida FP, Barbosa JC, Scott IU, Jorge R. 2008. Panretinal photocoagulation versus PRP plus intravitreal bevacizumab for high-risk proliferative diabetic retinopathy (IBeHi study). Acta Ophthalmol 86: $385-389$.

Tong Z, Yang Z, Patel S, Chen H, Gibbs D, Yang X, Hau VS, Kaminoh Y, Harmon J, Pearson E, et al. 2008. Promoter polymorphism of the erythropoietin gene in severe diabetic eye and kidney complications. Proc Natl Acad Sci 105: 6998-7003.

Verteporfin in Photodynamic Therapy Study Group. 2001. Verteporfin therapy of subfoveal choroidal neovascularization in age-related macular degeneration: Two-year results of a randomized clinical trial including lesions with occult with no classic choroidal neovascularization-verteporfin in photodynamic therapy report 2 . Am J Ophthalmol 131: 541-560.

Votruba M, Gregor Z. 2001. Neovascular age-related macular degeneration: Present and future treatment options. Eye (Lond) 15: 424-429.

Wakabayashi T, Oshima Y, Sakaguchi H, Ikuno Y, Miki A, Gomi F, Otori Y, Kamei M, Kusaka S, Tano Y. 2008. Intravitreal bevacizumab to treat iris neovascularization and neovascular glaucoma secondary to ischemic retinal diseases in 41 consecutive cases. Ophthalmology 115: 1571-1580.

Watanabe D, Suzuma K, Matsui S, Kurimoto M, Kiryu J, Kita M, Suzuma I, Ohashi H, Ojima T, Murakami T, et al. 2005. Erythropoietin as a retinal angiogenic factor in proliferative diabetic retinopathy. $N$ Engl J Med 353: $782-792$.

Wiegand TW, Rogers AH, McCabe F, Reichel E, Duker JS. 2009. Intravitreal bevacizumab (Avastin) treatment of choroidal neovascularisation in patients with angioid streaks. Br J Ophthalmol 93: 47-51.

Xia P, Aiello LP, Ishii H, Jiang ZY, Park DJ, Robinson GS, Takagi H, Newsome WP, Jirousek MR, King GL. 1996. Characterization of vascular endothelial growth factor's effect on the activation of protein kinase $\mathrm{C}$, its isoforms, and endothelial cell growth. J Clin Invest 98: 2018-2026.

Xiong SQ, Xia XB, Xu HZ, Jiang J. 2009. Suppression of retinal neovascularization by small-interference RNA targeting erythropoietin. Ophthalmologica 223: 306-312.

Zhang SX, Wang JJ, Gao G, Parke K, Ma JX. 2006. Pigment epithelium-derived factor downregulates vascular endothelial growth factor (VEGF) expression and inhibits VEGF-VEGF receptor 2 binding in diabetic retinopathy. J Mol Endocrinol 37: 1-12. 


\title{
$\&_{\mathrm{CSH}}^{\infty} \&$ Cold Spring Harbor

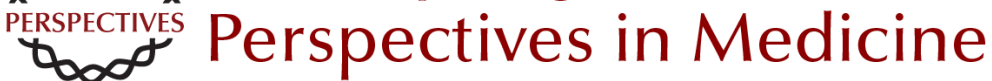

\section{Antiangiogenic Therapy for Ischemic Retinopathies}

\author{
Motasem Al-Latayfeh, Paolo S. Silva, Jennifer K. Sun and Lloyd Paul Aiello \\ Cold Spring Harb Perspect Med 2012; doi: 10.1101/cshperspect.a006411 originally published online \\ February 28, 2012
}

\section{Subject Collection Angiogenesis}

Extracellular Matrix Regulation of Vascular Morphogenesis, Maturation, and Stabilization George E. Davis and Scott S. Kemp

Endothelial Cell-Pericyte Interactions in the Pathogenesis of Cerebral Cavernous Malformations (CCMs) Wang Min and Jenny Huanjiao Zhou

Lymphatic Clearance and Pump Function Jerome W. Breslin

Platelets and (Lymph)angiogenesis Harvey G. Roweth and Elisabeth M. Battinelli

Modeling Brain Vasculature Immune Interactions In Vitro Ruth Lyck, Hideaki Nishihara, Sidar Aydin, et al.

Human Endothelial Colony-Forming Cells Juan M. Melero-Martin

\section{The Beauty and Complexity of Blood Vessel} Patterning

Victoria L. Bautch and Yoh-suke Mukouyama

Endothelialitis, Microischemia, and

Intussusceptive Angiogenesis in COVID-19 Steven J. Mentzer, Maximilian Ackermann and Danny Jonigk
Regulation of the Blood-Brain Barrier in Health and Disease Cara C. Rada, Kanako Yuki, Jie Ding, et al.

Targeting Angiogenesis via Resolution of Inflammation

Abigail G. Kelly and Dipak Panigrahy

Notch Signaling in the Vasculature: Angiogenesis and Angiocrine Functions

Sana S. Hasan and Andreas Fischer

Signal Transduction and Gene Regulation in the Endothelium

Michel V. Levesque and Timothy Hla

Buttons and Zippers: Endothelial Junctions in

Lymphatic Vessels

Peter Baluk and Donald M. McDonald

Endothelial Cell Fate Determination: A Top Notch Job in Vascular Decision-Making

L.A. Naiche, Stephanie R. Villa and Jan K. Kitajewski

Leukocyte Trafficking in Lymphatic Vessels Aline Bauer, Hazal Tatliadim and Cornelia Halin

Lymphatic Tissue and Organ Engineering for In Vitro Modeling and In Vivo Regeneration Anna M. Kolarzyk, Gigi Wong and Esak Lee

For additional articles in this collection, see http://perspectivesinmedicine.cshlp.org/cgi/collection/ 